\title{
Minority groups in Romania during the communist regime
}

\author{
Andrei Ghimisi ${ }^{1}$ \\ ${ }^{1}$ National University of Political Studies and Public Administration \\ E-mail: ghimisi4567@gmail.com
}

\begin{abstract}
The paper "Minority groups in Romania during the communist regime" aims to tackle the difficulties that the presented groups faced during the communist regime. The challenges that the respective groups faced were different in nature from economic to social inclusion and education. In this paper, relevant and defining methods are presented in order to understand the full length of the problems of the biggest (in number) minority groups and what they had to face in the communist regime
\end{abstract}

Keywords: minorities, public policies, communist regime

\section{Introduction}

Romania, as any other country in the world, faces challenges regarding the integration of minorities inside its society. Nowadays, more and more tools have been created in order to facilitate the integration of minorities from different areas of the world and also to create a proper environment for both the minorities, and the native people of the country to coexist and prosper. Such tools were very poor developed, or even didn't exist during the communist period in Romania.

After World War I, Romania and its population doubled, amounting around 18 million. An interesting aspect is that only two thirds of its people were Romanian of origin, one third being Hungarian, Jewish, German, Bulgarian, South Slavic, Ukrainian and, maybe the most important ethnic group, Roma people. Going for the French model, Romania created a highly centralized state organization, centralized around Bucharest. The challenge of governing a economically and culturally heterogeneous fragmented country was now in the hands of the Romanian elite.

After the Treaty of Trianon peace agreement, around 200.000 Hungarians emigrated back to Hungary. Despite this factor, the majority of inhabitants and elite in major Transylvanian cities were still of German, Jewish and Hungarian origin. The government of Romania began a forced assimilation process, but only until the communist came to power that this "forced assimilation" truly had meaning.

The Second World War was a crucial point for Romania and its development. In the beginning, Bucharest was an ally of Germany until 1944. During this time, the state lost Northern Transylvanian as it was given back to Hungary along with one million Romanian residents. In 1941, Romania regained Bessarabia from its eastern neighbor, the Soviet Union, and managed to bring back the inhabitants, which were mostly Romanian. In 1944, Romania switched sides realizing the imminent defeat of Germany and joined the Allies. This came with both ups and downs, Romania regaining the whole of Transylvania, but losing Bessarabia to the Soviet rule in the process. During the war, the majority of Romanian Jews were killed and the remaining survivors emigrated back to Israel in the late forties.

The communist and their rule didn't put and end to discrimination against Romanian ethnic minorities and moreover for the Hungarians it became far worse. The Hungarian cultural, political and 
religious elites were meant to be intimidated by a number of show trials, but many of those who were persecuted behaved courageously and remained steadfast. The castles, manor houses and lands of the Transylvanian Hungarian aristocrats were confiscated and many more were also deported to labor camps in the Danube Delta.

Going even further, one of the most discriminated and persecuted group of minorities, the Roma people, will suffer many problems at the hands of the communist regime.

\section{Minority groups and their challenges in the first part of the communist regime in Romania (1948-1965).}

The challenges that minority groups faced during the communist regime are numerous and different in nature. The focus is set upon the two main periods of communist Romania: from 1948 to 1965 when Gheroghe Gheorghiu Dej was leader of the state and from 1965 to 1989 when Nicolae Ceausescu ruled over Romania.

In the beginning of the communist regime, Romania's national minorities at the outset of the communist rule were seemingly well served by the Leninist approach. The Constitution provided them equal rights in "all field of economic, political, juridical, social and cultural life" and specifically guaranteed the free use of their native language and the right to education at all levels in their mother tongue.

From the beginning of the communist regime, large numbers of ethnic Romanians joined the party, and their share of total membership rose steadily over the years increasing from 79 percent in 1955 to almost 90 percent in the early 1980s. Even though the regime claimed that minority membership and representation in the Grand National Assembly and in the people's, council were commensurate with their size, minorities were mostly excluded from policy-making bodies on both national and local levels. Even in areas where Hungarian people represented a sizable portion of the population such as Arad, Timis and Maramures, few were found in local PCR bureaus. Going to the national level, the most important and powerful positions in the critical defense, foreign affairs and interior ministries were reserved for ethnic Romanians and minorities were consigned to rubber-stamp institutions.

A special attention was received by the large Hungarian minority with the establishment of the Hungarian Autonomous Region in 1952. Like many other generous provisions regarding nationalities, this concession tuned out to be an empty gesture and masked the true nature of relations between the minorities and the state. The region was never called "home" to more than one quarter of Romania's Hungarian population and it had no more autonomy than other administrative provinces. Even more, after the Hungarian Revolution in 1956, even the autonomy was curtailed. Going further, in 1960 directives from Bucharest aimed to reorganize and rename the province so that its Hungarian nature was even further reduce. The reorganization of the territory, by adding purely Romanian inhabited areas and excluding Hungarian enclaves, managed to increase the Romanian element in the province from 20 to 35 percent and reduced he Hungarian from 77 to 62 percent. The regions were renamed to Mures Autonomous Hungarian Region and thereafter was most often referred to simply as the Mures Region.

It is arguable that the when it comes to education, language and cultural heritage, the communist regime in Romania affected mostly the Hungarians and to lesser extent the Germans. The changes that limited education in their native languages were seen even from the first decade of communist rule. Students could acquire an education in Hungarian-language schools from preschool to university and for the German-language schools, from preschool to high school. But even from the beginning in 1948, some policies were aimed to weaken national minority education. A "reeducation" of faculty in all educational institutions was formed. From that time forward, only teachers that were deemed politically reliable filled out the important teaching positions. At the same time, the nationalization of all private 
and ecclesiastical schools destroyed the traditionally important rule of the church in the German and Hungarian educational systems.

In some communities, schools were merged so that ethnic Romanians constituted the majority of the student body. The regime imposed the teaching of Romanian in all educational institutions in order to 'prevent national isolation'. From 1957, the amalgamation of minority and Romanian schools became the rule rather than the exception. The newly emerged schools were formed of mostly ethnic Romanian directors, whereas Hungarias or Germans filled vice-director or vice-principal positions.

A major blow that was dealt to the Hungarian language education network was the merger of the Romanian Babez University with the Hungarian Bolyai University in Cluj. Because of such a merger, a larger enrollment of ethnic Romanians and a reduced availability of Hungarian language instruction was created. The party dictated what courses would be thought in Hungarian and the more technical courses were taught in Romanian only. It became impossible to study any of the applied sciences in Hungarian, thus restricting career opportunities for the Hungarian minority. The result was a predictable drop in the number of Hungarian undergraduates, from 10.75 percent in 1957 of all undergraduates to only 5.7 percent in 1974.

\section{Minority groups and their challenges in the second part of the communist regime in Romania (1965-1989).}

The year 1965 came with a change in power in the communist regime in Romania. Nicolae Ceausescu is elected as the new leader. In the same year, the Romanian Workers Party presented a new Constitution which proclaimed Romania a socialist unitary state. Thereafter, the country and its multinational character was in most part ignored, and the problem of cohabiting nationalities was officially considered resolved. Three year later, in 1965 the communist regime eliminated the Autonomous Hungarian Region outright.

The regime wanted to maintain the appearance of minority representation at all levels of government, official statistics showing that the part of people from ethnic minority communities employed in government positions were little of number. The reality was even harsher for minorities which had little real power of influence. Speaking at the local level, minority representatives, who were in general Romanianized, were mistrusted by their constituents. Although these spokespersons were in routine hand picked by the PCR, their loyalty for the regime was often suspected. A more accurate reflection of minority representation and participation was the ethnic composition of the party itself.

As Ceausescu rule went further, he started a campaign for de-Sovietization and self-determination in strong connection with a increasing Romanian nationalism in the domestic policy field. Emphasis was especially put on Romanian history, language and culture in order to enhance Ceausescu's popularity among the Romanian majority. In 1976 the PCR presented a nationwide campaign dedicated to the glorification of the Romanian homeland called: 'Hymm to Romania'. In this campaign, all nationalities were expected to join the fete, which placed the German and Hungarian minorities of Transylvania in a grievous predicament. The campaign saw to remove all traces of Hungarian and German territorial identification. In cities that were already Romanianized, artefacts and monuments representing links to the Saxon or Hungarian past were all eliminated, bilingual inscriptions were removed and streets alongside some cities were renamed to emphasize Romanian roots. Thus Cluj, one of Transylvania's most important Hungarian city became Cluj-Napoca.

Other crucial changes that can be seen during Ceausescu's rule that affected the minority groups, in large the people of Hungarian origin, are directed at the education field. In 1973 education laws that were introduced continued the assimilation that had begun earlier with the amalgamation of minority and Romanian schools. The laws emphasized technical studies over humanities in order to keep in touch with the economic program of rapid industrialization. In 1974, only 1.4 percent of the instruction on technical schools was in Hungarian. Also, technical textbooks were rarely translated into minority languages. 
Romanian leaders at that time claimed that the amalgamation of Romanian and minority schools in strong connection with the 1973 educational reforms were necessary for economic and administrative efficiency and were not intended to ensure the assimilation of ethnic minorities. Even though that claimed seemed to be plausible, other actions that diminished the ability of minorities to maintain their ethnic identity were not so readily explained. Over the decades, the gap between the theory and practice in the treatment of minorities widened as the assimilation of national minorities into a "harmonious hole" continued. The state and its discriminatory policies steadily diminished political, linguistic, constitutional and educational rights.

Another interesting factor regarding the status of minority groups in Romania during Nicolae Ceausescu's regime was the fact that even though the goal of the leader was national homogenization and an ethical pure Romania, the regime opposed emigration of ethnic minorities. A campaign was started in the late 1970's that followed two basic tacks. Spokespersons for the ethnic minorities in the workers councils praised the regime and its treatment of minorities and declared their devotion to socialist Romania. In contrast, those who wished to emigrate were presented as weaklings with underdeveloped "patriotic and political consciousness", traitors abandoning their fatherland and the struggle to build socialism.

These attempts to discourage emigration were not entirely left to the media. The official policy of the party allowed emigration only on a individual basis, and only in specific cases such as family reunification. In the years later, the PCR suggested ironically that families could be reunited by immigration in Romania. Obtaining permission to leave the country was a expensive, exhausting and lengthy process. Prospective emigrants were likely to be demoted to positions of lower pay and prestige or be fired from their jobs. They were also publicly evicted from their homes. Other measures in order to discourage the minorities were the rejection of their children to enroll in schools and the denial of medical care and other social benefits.

\section{The Roma population and their challenges during the communist regime in Romania}

The history of the Roma population during the communist regime is even harder to reconstruct than for the years of the Second World War. There were no policies directed directly at the Roma population for a long time in Romania. Even more, at the end of the 1970's and the beginning of the 1980s the authorities did decide to find a solution to the social situation of the Roma and took action in this direction, to certain extent even though the policies were not made public.

After the Transnistrian episode, the Roma people who survived deportation returned to their villages, while other nomads settle on the edges of Bucharest. The General Union of Roma in Romania and its leader Gheorghe Niculescu resumed their activity, without producing any publication. The Union was the disbanded in 1949 by the Communist authorities together with all other organizations that did not fit in the totalitarian system. This comes in contrast with the 1946 electoral campaign, when the Bloc of Democratic Parties, the electoral alliance headed by the communist party, sent our special manifestations to the Roma, addressing them as 'Brothers and Sisters Roma!' [1], This was just an electoral move as for many years the authorities paid no attention to the fate of the Roma

The year 1948 is the moment when the communist regime established itself in Romania and with it the Roma population wiped out from any official documents of political nature. The Roma population were not represented as an ethnic group at the level of the state administration and Party. Also, there were no institutions that could promote their collective interests and to deal specifically with the problems of this minority, within the limits of the totalitarian Communist State. Even in the end of the 1960s when a new form of representations for minorities was introduced, there was no national council of workers of Roma nationality. For almost three decades, until the late 1970s, the communist regime did not pay any attention the fate of the Roma population, as there were no special policies dedicated directly for them. 
The social and the economic transformations that took place in Romania during the communist regime also affected the Roma. The process of industrialization and urbanization, the nationalization of the economy, the transformation of the village as a result of the collectivization of agriculture, the policy of social "'homogenization" the occupational changes that took place, all of these changes could not fail to affect the Roma people.

One transformation that affected alone this population was the sedentarization of the Roma people who still practiced nomadism in one form or another. In the 1960's, the nomadic Roma were settled by the authorities in fixed settlements [2]. The result was, however, not the one that was expected. Even if they were provided with houses, the Roma people continues to live in a tent pitched in the yard, with the house being used as a stable for horses. The number of nomadic and semi-nomadic Roma people was estimated by the authorities in 1977 to be around 65.000 .

In regards to the economic transformation that took place in the communist regime in Romania, it affected the Roma population to very big extent. This transformation resulted in the gradual disappearance of the specific occupations and traditional crafts of the Roma population. In the new social and economic context, Roma people who still practiced their old crafts were forced to take up modern occupations and professions. Different groups of gypsies tried to adapt to these demands in specific wats. For example, there was a new role for the old blacksmiths in construction and heavy industry. In towns, Roma people were able to find work in factories and also street-cleaning jobs became an area in which they held a virtual monopoly. In the last period of the communist regime, even the agricultural co-operatives summoned sometimes the Roma to work, even though they were not members of the respective co-operative.

To a certain extent, some of the traditional occupations of the Roma population nonetheless survived. In areas of the country, the brick that was required was supplied by the ones who were specialized in crafts. The price of the work would be bargained when they would install themselves along with their entire family on the boundary of the respective village. This was a seasonal occupation. They were also presented into rudari, which would manufacture wooden objects, or caldari, which would manufacture cooper goods for the distilling of brandy.

In 1977, an analysis of the situation of the Roma people was carried out by the Central Committee of the Romanian Communist party and it initiated a special program designed to integrate them into society. The program was never made public and researchers alongside historians do not even have access to the archives of the period. Until now, only the report that was compiled in 1983 by the Propaganda Section of the Central Committee of the Romanian Communist Party, in which an assessment of the result achieved until that point, has been published [3].

As a general characterization, the Roma population in Romania during the communist regime went under a significant occupational transformation. Most of them were forced to abandon their occupations that had been for a long time characteristic for them and to find their place in the communist- type economy.

\section{Conclusion}

In conclusion, the minority groups in Romania suffered many transformations during the communist regime in Romania. The German, Hungarian and Roma groups were the most affected by the rise to power of the communist. In regards to the German and Hungarian minorities inside the Transylvanian territory, the communist regime seeked to wipe out almost every existence of their stay in the respective territory.

Not only that, but more important by reshaping the educational field so as the Hungarian schools no longer exist and there would be only mixed schools in which the teaching ,especially for the high technical courses, would be only in the Romanian language, the communist regime offered a clear view 
on how they see their heritage protected. Because of these forced measures and others such as the renaming of cities and the merger of universities, the Hungarian minorities were forced to either compel with the situation or leave.

The Roma people were also one of the most important ethnic groups that suffered during the communist regime. The social and economic context presented by the communist regime was, in large terms, hard to adapt by the Roma population.

\section{References}

[1] Merfea, M.,(1991), Tiganii-Integrarea socială a romilor, Ed. Brasa, Braşov

[2] Cherata, C.L.(1992), Istoria ţiganilor (Origine, specific, limbă) Editura Z, Bucuresti

[3] Cartner, H., (1991), Destroying Ethnic Identity, The persecution of Gypsies in Romania, Ed. Human Rights Watch 